\title{
BIOSORPSI TIMBAL OLEH BIOMASSA DAUN KETAPANG
}

\section{LEAD BIOSORPTION USING BIOMASS FROM KETAPANG LEAF}

\author{
Reza Mulyawan ${ }^{1}$, Asep Saefumillah ${ }^{2}$, Foliatini ${ }^{1}$ \\ ${ }^{1}$ Akademi Kimia Analisis Bogor \\ ${ }^{2}$ Departemen Kimia FMIPA Universitas Indonesia \\ Email : rezamulyawan@yahoo.com
}

\begin{abstract}
ABSTRAK
Limbah yang mengandung logam berat timbal $(\mathrm{Pb})$ sangat berbahaya bagi lingkungan. Proses pengolahan telah diperkenalkan untuk mengolah limbah, dari proses pengendapan, hingga menggunakan resin penukar ion. Daun ketapang telah di gunakan sebagai media pengolahan air yang digunakan untuk akuarium. Para peneliti telah menunjukkan daun ketapang berpotensi sebagai pengolah air limbah. Penelitian ini bertujuan untuk mengetahui potensi biosorpsi daun ketapang pada limbah yang tercemar logam berbahaya, dengan mempelajari karakteristik biosorpsi, kesetimbangan, kinetika dan termodinamika. Kondisi optimum seperti $\mathrm{pH}$, dosis daun ketapang, waktu kontak dan suhu akan diamati pada penelitian ini. Hasil Penelitian biomassa daun ketapang berpotensi sebagai biosorben, dengan perlakuan asam atau basa daun ketapang ini masih berpotensi sebagai biosorben. Penyerapan sangat dipengaruhi oleh $\mathrm{pH}$, konsentrasi ion $\mathrm{Pb}$, massa adsorben, waktu kontak dan suhu, yang berurutan nilai maksimum nya adalah $\mathrm{pH} 3$, konsentrasi ion $\mathrm{Pb} 5 \mathrm{mg} / \mathrm{L}$, massa adsorben 0,5 gram, waktu kontak 4 jam, dan suhu $40^{\circ} \mathrm{C}$. Laju reaksi berjalan pada orde satu dan memenuhi kaidah isotermal Langmuir. Daun ketapang memiliki energi aktivasi yang rendah sehingga cocok untuk dijadikan adsorben alternatif penyerapan logam $\mathrm{Pb}$ dari limbah yang mengandung logam $\mathrm{Pb}$.
\end{abstract}

Kata kunci: Adsorpsi, daun ketapang, timbal $(\mathrm{Pb})$

\begin{abstract}
Waste containing of lead $(\mathrm{Pb})$ is very dangerous for the environment. However, waste treatment process has been introduced to minimize the waste, either by precipitation process or ionic exchange resin. In addition, researchers have shown that ketapang leaves (Terminalia catappa) can be potentially used in waste water treatment. It has been used as water treatment media for fresh water aquarium. Moreover, this research was aimed to find out the potential of ketapang leaves biosorption for waste treatment that has been polluted by heavy metal, such as lead, by investigating the characteristics of biosorption, kinetics and thermodynamics. Maximum conditions of $\mathrm{pH}$, ketapang leaves dose, contact time, and temperature were also investigated in this research. The result showed that biomass of ketapang leaves has potential as biosorbent. Nevertheless, the absorbtion was highly affected by dependent to $\mathrm{pH}, \mathrm{Pb}$ concentration, adsorbent mass, contact time, and temperature, in which the maximum limits are 3; $5 \mathrm{mg} / \mathrm{L} ; 0.5$ gram; 4 hours; $40{ }^{\circ} \mathrm{C}$; respectively. Reaction rate, moreover, was running
\end{abstract}


on order one and was fulfilled the principle of Langmuir. Ketapan leaves have a low activation energy making it suitable to be used as an alternative adsorbent $\mathrm{Pb}$ absorption of waste containing $\mathrm{Pb}$.

Key words: Adsorption, Lead (Pb), Ketapang leaf.

\section{PENDAHULUAN}

Pengolahan dengan cara pengendapan menggunakan koagulan yaitu mengolah limbah dengan menambahkan sejumlah bahan kimia yang bersifat mengendapkan limbah, sehingga terbentuk sedimentasi yang akan terendapkan di dasar. Kelebihan dari pengolahan dengan sedimentasi adalah tingkat efektivitas yang baik, tetapi membutuhkan lahan yang luas dan proses yang lama sekitar 24 hingga 48 jam.

Berbagai adsorben telah diaplikasikan untuk mengolah limbah logam berat dalam limbah cair, diantaranya: Penggunaan zeolit oleh Chao dan Chang (2012), penggunan arang aktif oleh Zabihi et.al. (2009) dan penggunaan daun ketapang sebagai biosorben untuk logam paladium dan platina oleh Ramakul (2012). Pengolahan limbah logam berat menggunakan adsorpsi merupakan pengolahan yang sederhana namun menghasilkan efisiensi yang tinggi. Metode adsorpsi menggunakan biomassa disebut juga biosorpsi, yaitu menggunakan adsorben dari biomassa sebagai penyerap ion logam yang terkandung dalam limbah sehingga kandungan ion logam dalam air limbah menjadi turun. Walaupun zeolit dan arang aktif banyak digunakan dalam pengolahan limbah mengandung logam berat, tetapi masih terdapat kelemahan, yaitu proses pembuatan yang cukup rumit dan memerlukan aktivator untuk kontak dengan logam berat.

Alternatif adsorben lain yang dapat digunakan adalah adsorben berbasis biomaterial yaitu yang berupa bagian dari tumbuhan. Adsorben jenis ini disebut biosorben dan potensial untuk dimanfaatkan dalam pengolahan limbah yang ramah lingkungan dan berbiaya rendah. Contohnya adalah penggunaan alga hijau oleh Mawardi (2007) sebagai adsorben logam berat dan Klimmek et.al. (2001).

Daun ketapang (Terminalia catappa) adalah sejenis pohon tepi pantai yang rindang dan banyak ditanam sebagai peneduh di pinggir jalan. Sejak dahulu daun ketapang banyak digunakan sebagai media yang membantu akuarium dalam pengolahan airnya. Salah satu ikan hias yang cocok dengan daun ketapang sebagai media biosoprsi adalah ikan cupang. Stephen dan Sulochana (2006) dan dikuatkan oleh penelitian Zabihi et.al (2009) yang telah melakukan pengolahan limbah yang mengandung merkuri dengan menggunakan ekstrak buah ketapang. Ramakul (2012) dapat membuktikan daun ketapang dapat digunakan sebagai biomassa pereduksi ion logam paladium $\left(\mathrm{Pd}^{2+}\right)$ dan platinum $\left(\mathrm{Pt}^{4+}\right)$. Karena ketersediaan biomaterial daun ketapang yang cukup tinggi dan efektifitasnya cukup baik dan tinggi maka biomaterial tersebut dapat diuji lebih lanjut untuk adsorben logam lain salah satunya logam timbal.

\section{METODOLOGI PENELITIAN}

Penelitian terdiri atas dua tahap, yaitu (1) preparasi biomassa daun ketapang, (2) pengujian biosorpsi $\mathrm{Pb}^{2+}$ dan biosorben daun ketapang dengan meneliti pengaruh waktu, $\mathrm{pH}$, konsentrasi biomassa, konsentrasi $\mathrm{Pb}$, suhu, termodinamika dan kinetika. Penelitian ini berlangsung selama 7 bulan. 
Alat-alat yang dipakai adalah AAS Shimadzu 6300, FTIR Bruker, Milipore Water Purifier, $\mathrm{pH}$ Meter Agilent, SEM EDAX, Shaker Thermo Science, Hot plate Thermo Science, Neraca analitik AND, Oven Memmert, Stiring hot plate Thermo Science, Blender Phillips, Peralatan gelas Iwaki, Termometer.

Bahan yang dipakai daun ketapang, kertas saring Whatman 40, 41, 42, Standar $\mathrm{Pb}$ dari Merck, asam klorida dari Merck, Natrium hidroksida dari Merck, Natrium bikarbonat dari Merck, Air demin, Lantanum Klorida dari Merck.

\section{Preparasi Biosorben Daun Ketapang}

Daun ketapang dicuci dengan akuabides, dikeringkan dalam oven dengan suhu $70{ }^{\circ} \mathrm{C}$ selama 48 jam, dilanjutkan dengan pengeringan dalam oven pada suhu $70{ }^{\circ} \mathrm{C}$ selama 48 jam. Daun ketapang yang sudah kering kemudian diblender hingga halus.

\section{a. Daun Ketapang dengan Perlakuan Penambahan Asam}

Daun ketapang yang sudah dihaluskan dilarutkan dalam $\mathrm{HCl} 0,1 \mathrm{~N}(10 \mathrm{~g}$ daun ketapang/L $\mathrm{HCl} \quad 0,1 \mathrm{~N}$ ), direndam selama 3 jam, kemudian disaring, biomassa yang tertahan di kertas saring dicuci dengan air demin hingga netral, dilanjutkan dengan pengeringan biomasssa dalam oven suhu 70 ${ }^{\circ} \mathrm{C}$ selama 48 jam.

\section{b. Daun Ketapang dengan Perlakuan Penambahan Basa}

Daun ketapang yang sudah dihaluskan dilarutkan dalam $\mathrm{NaOH} 0,1 \mathrm{~N}$ (10 g daun ketapang/L $\mathrm{NaOH} \quad 0,1 \mathrm{~N}$ ), direndam selama 3 jam, kemudian disaring, biomassa yang tertahan di kertas saring dicuci dengan air demin hingga netral, dilanjutkan dengan pengeringan biomasssa dalam oven suhu $70^{\circ} \mathrm{C}$ selama 48 jam.

\section{Karakterisasi Proses Adsorpsi $\mathbf{P b}^{2+}$ Dengan Pengaruh Waktu Kontak}

Sebanyak $200 \mathrm{~mL}$ larutan yang mengandung $\mathrm{Pb}^{2+}$ dalam Erlenmeyer 250 $\mathrm{mL}$ ditambahkan $0,5 \mathrm{~g} / \mathrm{L}$ adsorben. Larutan diaduk menggunakan shaker dengan kecepatan $100 \mathrm{rpm}$ selama 5 jam. Setiap 0,5 jam larutan tersebut di sampling $10 \mathrm{~mL}$ dilakukan pengukuran konsentrasi $\mathrm{Pb}^{2+}$ dalam larutan secara AAS. Konsentrasi akhir $\mathrm{Pb}^{2+}\left(\mathrm{C}_{\mathrm{t}}\right)$ dihitung dengan menggunakan kurva kalibrasi. Konsentrasi $\mathrm{Pb}^{2+}$ yang terserap (C) merupakan selisih dari $\mathrm{C}_{\mathrm{t}}$ dengan $\mathrm{C}_{0}$. Sementara kapasitas adsorpsi didapat dari selisih $\mathrm{C}_{\mathrm{t}}$ dengan $\mathrm{C}_{0}$ dan dikalikan dengan volume larutan serta dibagi massa adsorben. Efektivitas \% adsorpsi dan kapasitas adsorpsi dihitung berdasarkan persamaan berikut:

$$
\begin{gathered}
\text { \% Adsorpsi (efektivitas) }=\frac{\mathrm{C}_{\mathrm{t}}-\mathrm{C}_{0}}{\mathrm{C}_{\mathrm{t}}} \times 100 \\
\text { Kapasitas Adsorpsi } \mathrm{q}_{\mathrm{t}}\left(\frac{\mathrm{mg}}{\mathrm{g}}\right)=\frac{\left(\mathrm{C}_{\mathrm{t}}-\mathrm{C}_{0}\right) \times \mathrm{V}}{\mathrm{W}}
\end{gathered}
$$

Keterangan : $\mathrm{C}_{\mathrm{t}}=$ Konsentrasi akhir $\mathrm{Pb}^{2+}(\mathrm{mg} / \mathrm{L})$

$$
\begin{aligned}
& \mathrm{C}_{0}=\text { Konsentrasi akhir } \mathrm{Pb}^{2+}(\mathrm{mg} / \mathrm{L}) \\
& \mathrm{W}=\text { Bobot biosorben }(\text { gram })
\end{aligned}
$$

\section{Karakterisasi Proses Adsorpsi $\mathbf{P b}^{2+}$ dengan Pengaruh Suhu}

Sebanyak $100 \mathrm{~mL}$ larutan yang mengandung $\mathrm{Pb}^{2+}$ dalam Erlenmeyer 250 $\mathrm{mL}$ ditambahkan $0,5 \mathrm{~g} / \mathrm{L}$ adsorben. Larutan diaduk menggunakan shaker dengan kecepatan 100 rpm dipanaskan pada suhu 30 ; $40 ; 50 ; 60 ; 70 ; 80{ }^{\circ} \mathrm{C}$ selama 3 jam dan larutan disaring dengan filter Whatman 42 
lalu filtrat dilakukan pengukuran konsentrasi $\mathrm{Pb}^{2+}$ dalam larutan secara AAS.

\section{Karakterisasi Proses Adsorpsi $\mathbf{P b}^{2+}$ dengan Pengaruh pH}

Sebanyak $200 \mathrm{~mL}$ larutan yang mengandung $\mathrm{Pb}^{2+}$ dalam Erlenmeyer 250 $\mathrm{mL}$ ditambahkan 0,5 g/L adsorben. Larutan diaduk menggunakan shaker dengan kecepatan $100 \mathrm{rpm}$, di kondisikan $\mathrm{pH} 2 ; 3$; $4 ; 5 ; 6 ; 7 ; 8 ; 9 ; 10$ selama 3 jam dan larutan disaring dengan filter Whatman 42 lalu filtrat dilakukan pengukuran konsentrasi $\mathrm{Pb}^{2+}$ dalam larutan secara AAS.

\section{Karakterisasi Proses Adsorpsi $\mathbf{P b}^{2+}$ Dengan Pengaruh Massa Adsorben}

Disiapkan sebanyak 10 beaker glass $250 \mathrm{~mL}$ berisi larutan $\mathrm{Pb}^{2+} 100 \mathrm{~mL}$, satu diantaranya sebagai blanko diaduk menggunakan shaker dengan kecepatan 100 rpm, ditambahkan adsorben sebanyak 0,1 ; 0,$2 ; 0,3 ; 0,4 ; 0,5 ; 1 ; 2 ; 3 ; 4$, dan 5 gram adsorben ke dalam masing-masing beaker glass diproses selama 3 jam dan larutan disaring dengan filter Whatman 42 lalu filtrat dilakukan pengukuran konsentrasi $\mathrm{Pb}^{2+}$ dalam larutan secara AAS.

\section{Karakterisasi Proses Adsorpsi $\mathbf{P b}^{2+}$ dengan Pengaruh Konsentrasi Ion $\mathbf{P b}^{2+}$}

Sebanyak $200 \mathrm{~mL}$ larutan yang mengandung $\mathrm{Pb}^{2+}$ dalam Erlenmeyer 250 $\mathrm{mL}$ ditambahkan 0,5 g/L adsorben. Larutan diaduk menggunakan shaker dengan kecepatan 100 rpm, dikondisikan konsentrasi larutan $\mathrm{Pb} 0 ; 5 ; 10 ; 15 ; 20 ; 25 \mathrm{mg} / \mathrm{L}$ diproses selama 3 jam dan larutan disaring dengan filter Whatman 42 lalu filtrat dilakukan pengukuran konsentrasi $\mathrm{Pb}^{2+}$ dalam larutan secara AAS.

\section{Kinetika Biosorpsi}

Dari konsentrasi $\mathrm{Pb}^{2+}$ yang terserap (C) diplotkan terhadap waktu sesuai dengan beberapa persamaan orde reaksi yang diuji, yaitu orde 1, 2, dan 3. Dengan demikian diperoleh kurva $\ln \mathrm{C}$ terhadap waktu (t) untuk orde 1 , kurva $1 / \mathrm{C}$ terhadap waktu $(\mathrm{t})$ untuk orde 2 , dan kurva $1 / \mathrm{C}^{2}$ terhadap waktu (t) untuk orde 3. Masing-masing kurva dihitung nilai korelasi (r) dari ketiga orde reaksi, kurva dengan nilai $\mathrm{r}$ mendekati nilai 1 maka menunjukkan bahwa kurva tersebut paling linier dan kinetika orde reaksi mengikuti orde yang dinyatakan dalam kurva tersebut.

\section{Model Isotermal Biosorpsi}

Model isotermal biosorpsi diuji dengan persamaan Langmuir. Untuk persamaan Langmuir dibuat plot antara 1/C terhadap 1/qe. Dengan ploting 1/Ce dan 1/qe untuk memenuhi persamaan Langmuir.

\section{Karakterisasi FTIR}

Daun ketapang yang sudah dikeringkan dan sudah diaplikasikan sebagai biosorben untuk larutan yang mengandung $\mathrm{Pb}^{2+}$ dikarakterisasi dengan alat FTIR. Sampel 0,1 gram di masukan ke dalam tempat sampel yang berbentuk bulat, pastikan semua permukaan tertutupi sampel, dikarakterisasi dengan dengan sumber lampu IR dengan bilangan gelombang $500-4000$ $\mathrm{cm}^{-1}$.

\section{Karakterisasi SEM EDAX}

Daun ketapang yang sudah dikeringkan dan sudah diaplikasikan sebagai biosorben untuk larutan yang mengandung $\mathrm{Pb}^{2+}$ dikarakterisasi dengan alat SEM EDAX pada perbesaran 500 - 10000 kali.

\section{HASIL DAN PEMBAHASAN}

Penelitian ini memanfaatkan daun ketapang sebagai biosorben logam berat $\mathrm{Pb}^{2+}$, karena daun ketapang relatif mudah ditemukan dan proses adsorpsi dapat berlangsung secara sederhana serta tidak membutuhkan instrumentasi yang rumit. Sebelum dan sesudah diaplikasikan pada larutan yang mengandung $\mathrm{Pb}^{2+}$ 
dikarakterisasi dengan FTIR dan SEM EDAX untuk mengetahui potensi gugus aktif yang dapat dijadikan gugus aktif penyerap $\mathrm{Pb}^{2+}$ serta untuk melihat apakah $\mathrm{Pb}^{2+}$ terserap oleh biosorben.

\section{FTIR}

Karakterisasi awal dari biomassa daun ketapang melalui analisis gugus fungsi dalam biomassa dengan menggunakan FTIR dapat dilihat pada Gambar 1. Spektra FTIR biomassa daun ketapang memperlihatkan hasil pita serapan $3271 \mathrm{~cm}^{-1}$ yang merupakan uluran $-\mathrm{OH}$ (alkohol). Pita serapan $2971 \mathrm{~cm}^{-1}$ merupakan uluran $\mathrm{O}-\mathrm{H}$ (karboksilat) dan $2850 \mathrm{~cm}^{-1}$ merupakan uluran $\mathrm{C}-\mathrm{H}$ (gugus $\mathrm{CH}, \mathrm{CH}_{2}$, dan $\mathrm{CH}_{3}$ ).

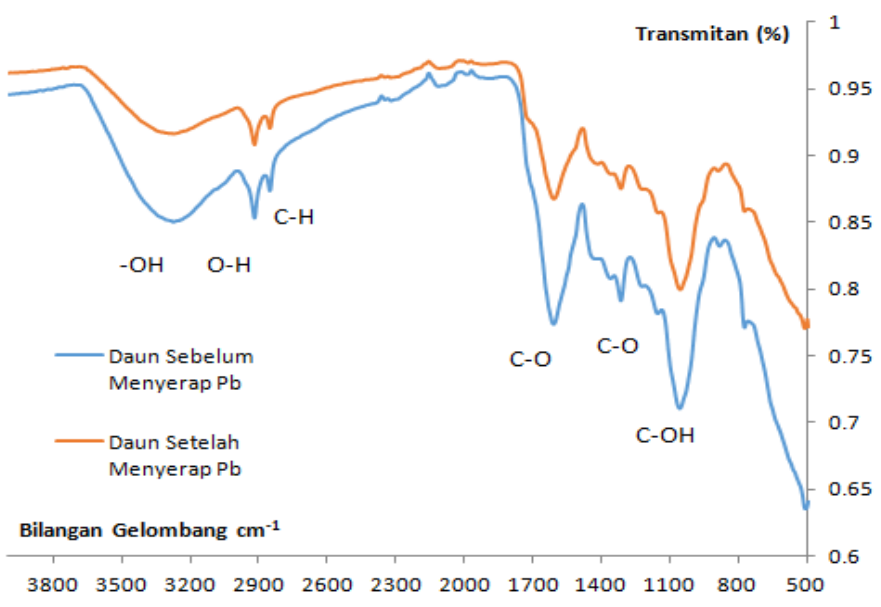

Gambar 1. Spektra FTIR Daun Ketapang

Berdasarkan hasil FTIR yang dapat dilihat pada Gambar 1 diketahui bahwa pita serapan $1610 \mathrm{~cm}^{-1}$ merupakan uluran C-O karboksil, diperkuat oleh pita serapan 1316 $\mathrm{cm}^{-1}$ merupakan uluran uluran $\mathrm{C}-\mathrm{O}$ karboksil, serta pita serapan $1059 \mathrm{~cm}^{-1}$ merupakan gugus alkohol primer $(\mathrm{C}-\mathrm{OH})$. Spektra IR dari daun ketapang yang telah diaplikasikan terhadap larutan yang mengandung $\mathrm{Pb}^{2+}$ dapat dilihat pada Gambar 1. Spektra FTIR biomassa daun ketapang memperlihatkan hasil pita serapan $3271 \mathrm{~cm}^{-1}$ yang merupakan uluran $-\mathrm{OH}$ (alkohol). Pita serapan $2971 \mathrm{~cm}^{-1}$ dan 2850 $\mathrm{cm}^{-1}$ merupakan uluran $\mathrm{O}-\mathrm{H}$ (karboksilat) dan uluran $\mathrm{C}-\mathrm{H}$ (gugus $\mathrm{CH}, \mathrm{CH}_{2}$, dan $\mathrm{CH}_{3}$ ), dan pita serapan $1059 \mathrm{~cm}^{-1}$ merupakan gugus alkohol primer $(\mathrm{C}-\mathrm{OH})$.

Terdapat pergeseran pita serapan pada biomassa sebelum dan sesudah di aplikasikan pad larutan yang mengandung $\mathrm{Pb}^{2+}$, seperti terlihat pada Gambar 1 telah bergeser hingga $10 \mathrm{~cm}^{-1}$. Hal ini dapat terjadi karena telah terjadi perubahan gugus fungsi yang telah mengikat $\mathrm{Pb}^{2+}$, penelitian Mawardi (2007) mengemukakan hal yang sama yaitu telah terjadi pergeseran bilangan gelombang saat biomassa alga hijau mengikat logam dibandingkan dengan sebelum mengikat logam.

\section{SEM EDAX}

Karakterisasi dengan SEM-EDAX bertujuan untuk melihat topografi dari hasil penyerapan pada permukaan adsorben. Pada hasil SEM-EDAX diperoleh hasil gambar hitam dan putih/gelap terang, hasil ini dipengaruhi dari unsur penyusunnya. Unsur logam akan akan memberikan warna putih terutama logam $\mathrm{Pb}$. 
Karakterisasi daun ketapang dengan menggunakan SEM-EDAX memperoleh hasil seperti yang tertera pada Tabel 1 . Penyusun utama dari biomassa daun ketapang adalah $\mathrm{C}$ dan $\mathrm{O}$ dan unsur logam, ini sesuai dengan penelitian Chyau et.al (2006) daun ketapang mengandung 15,2\%, $13,3 \%, 17,2 \%, 17,8 \%, 31,4 \%$ dan $5,1 \%$ berurutan asam p-hidroksibenzoat, asam 4hidroksi phenil propionat, asam m-kumarat, asam 3,4-dihidroksibenzoat, asam p-kumarat dan asam galat. Keberadaan logam timbal di daun ketapang berasal dari paparan timbal yang bersumber dari transportasi, karena daun diambil dari tanaman yang tumbuh dipinggir jalan. Hal ini diperkuat oleh Lim (2012) yang menyatakan selain antioksidan dan tanin, daun ketapang juga mengandung cemaran logam berbahaya yang salah satunya adalah $\mathrm{Pb}$. Ismayadi (2010) meneliti kandungan timbal pada daun tanaman yang tumbuh di pinggir jalan, salah satunya daun tanaman ketapang, dan mendapatkan kandungan timbal dalam daun ketapang sebesar 0,2 $\mathrm{mg} \mathrm{Pb} / \mathrm{Kg}$ daun ketapang.

Berdasarkan Gambar 1 dapat dilihat bahwa serapan $\mathrm{Pb}$ sebelum dan setelah proses dapat terlihat perbedaan, ion $\mathrm{Pb}$ terikat kepermukaan daun ketapang, dan hasil ini dibuktikan pula dengan kenaikan konsentrasi $\mathrm{Pb}$ hasil analisis komposisi SEM-EDAX Tabel 1 dengan kenaikan dari $0,85 \%$ menjadi $1,54 \%$. Meskipun SEMEDAX dapat menghitung \% berat namun pada umumnya perhitungan secara kuantitatif tidak menggunakan teknik instrumentasi tersebut.

Tabel 1. Karaterisasi SEM-EDAX

\begin{tabular}{cccccccc}
\hline Daun & $\begin{array}{c}\mathbf{C} \\
(\boldsymbol{\%} \mathbf{b} / \mathbf{b})\end{array}$ & $\begin{array}{c}\mathbf{O} \\
(\boldsymbol{\%} \mathbf{b} / \mathbf{b})\end{array}$ & $\begin{array}{c}\mathbf{N a} \\
(\boldsymbol{\%} \mathbf{b} / \mathbf{b})\end{array}$ & $\begin{array}{c}\mathbf{M g} \\
(\boldsymbol{\%} \mathbf{b} / \mathbf{b})\end{array}$ & $\begin{array}{c}\mathbf{S i} \\
(\boldsymbol{\%} \mathbf{b} / \mathbf{b})\end{array}$ & $\begin{array}{c}\mathbf{P b} \\
(\boldsymbol{\%} \mathbf{b} / \mathbf{b})\end{array}$ & $\begin{array}{c}\mathbf{C a} \\
(\boldsymbol{\%} \mathbf{b} / \mathbf{b})\end{array}$ \\
\hline Sebelum $^{*}$ & 60,28 & 30,67 & 1,14 & 1,13 & 4,43 & 0,85 & 1,30 \\
Sesudah $^{*}$ & 47,05 & 39,36 & 0,47 & 1,18 & 2,85 & 1,54 & 7,55 \\
\hline
\end{tabular}

*sebelum dan sesudah menyerap $\mathrm{Pb}$

\section{Waktu Optimum}

Pengaruh waktu kontak pada proses penyerapan kation $\mathrm{Pb}^{2+}$ di gambarkan oleh grafik pengaruh waktu kontak. Berdasarkan data diperoleh, waktu yang dibutuhkan untuk menyerap secara maksimum berada pada 3,5 jam untuk daun ketapang murni. Dari grafik juga diperoleh bahwa setelah waktu kontak optimum proses penyerapan kation $\mathrm{Pb}^{2+}$ berjalan stabil setelah kesetimbangan tercapai. Biomassa daun ketapang terlihat bahwa pada menit-menit awal penyerapan $\mathrm{Pb}^{2+}$ berlangsung dengan intensif, hal ini ditunjukkan dengan nilai \% adsorpsinya yang meningkat tajam. Jika dibandingkan antara ketiga biosorben terlihat bahwa biosorben dengan perlakuan asam memiliki \% adsorpsi lebih tinggi dari biosorben yang lainnya. Gambar 2 menunjukkan kesetimbangan terjadi pada 3,5 jam untuk biosorben daun murni kapasitas adsorpsi yang dinyatakan sebagai jumlah ion logam yang terserap (dalam mg) untuk setiap satuan berat adsorben. Hasil perhitungan kapasitas serapan dengan pengaruh waktu di gambarkan oleh Gambar 2. Nilai kapasitas adsorpsi sebagai fungsi waktu memiliki pola yang sama dengan kenaikan kapasitas adsorpsi pada waktu optimum, yaitu setelah tercapai waktu kesetimbangan. 


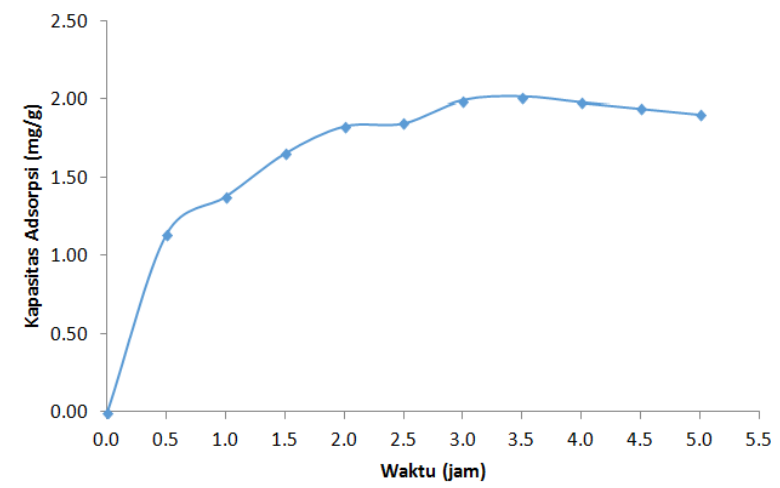

Gambar 2. Hubungan Kapasitas Adsorpsi dengan Waktu.

Pengaruh waktu kontak dalam adsorpsi juga dikemukan oleh Largitte (2014) yang mendapatkan bahwa kapasitas adsorpsi $\mathrm{Pb}^{2+}$ akan meningkat seiring waktu berjalan walaupun adsorben yang digunakan adalah menggunakan presipitasi. Sementara Plazinski menggambarkan pendekatan permodelan adsorpsi untuk multi komponen dimana Plazinski menyatakan bahwa waktu kontak adalah salah satu faktor yang signifikan dalam proses adsorpsi ion logam.

\section{Pengaruh pH}

Proses penyerapan ion logam berat oleh biomassa sangat dipengaruhi oleh $\mathrm{pH}$, beberapa penelitian terdahulu menunjukkan hal tersebut. Jiang et.al (2012) mendapatkan bahwa kation $\mathrm{Pb}$ terserap oleh biosorben secara maksimal pada $\mathrm{pH}$ asam (1-6). Sementara Freitas et.al (2011) menerangkan bahwa kation $\mathrm{Pb}$ dapat optimum diserap menggunakan biomassa pada $\mathrm{pH}$ 5, dimana biomassa yang digunakan adalah Aschophyllum nodosum. Menurut penelitian tersebut hal ini disebabkan oleh $\mathrm{Pb}^{2+}$ yang merupakan ion logam bersifat asam, akan bereaksi secara optimum saat kondisi lingkungan bersifat asam $\mathrm{pH}$ 1-6. Penelitian ini juga ditemukan pengaruh $\mathrm{pH}$ dalam adsorpsi $\mathrm{Pb}^{2+}$ oleh biosorben daun ketapang sangat besar. Peningkatan adsorpsi meningkat seiring meningkatnya nilai $\mathrm{pH}$. Pada nilai $\mathrm{pH}$ awal 2 adsorpsi meningkat tajam hingga pH maksimum 3-4 dan kembali menurun seiring kenaikan $\mathrm{pH}$ menuju basa. Proses ini dipengaruhi oleh reaksi yang melibatkan pertukaran ion-ion logam dengan gugus-gugus fungsi yang terkandung dalam adsorben. Gugus karboksil, karbonil, dan terutama gugus hidroksi yang terkandung dalam adsorben dapat mengikat ion logam dari larutan. Nilai $\mathrm{pH}$ optimum dari proses adsorpsi ini adalah 3. Dengan $\mathrm{pH}$ asam gugus-gugus tersebut di atas dapat bereaksi dengan $\mathrm{Pb}^{2+}$. Kondisi $\mathrm{pH}$ yang lebih besar dari 2 menghasilkan kapasitas adsorpsi daun cenderung tinggi, namun pada $\mathrm{pH} 6 \%$ adsorpsi dan kapasitas adsorpsi menurun tajam, seperti di gambarkan oleh Gambar 3. Pengaruh $\mathrm{pH}$ terjadi karena pada $\mathrm{pH} 2$ hingga $\mathrm{pH} 4 \mathrm{~Pb}$ berbentuk $\mathrm{Pb}^{2+}$ garam asam yang dapat berinteraksi dengan gugus-gugus dari biomassa, tetapi saat $\mathrm{pH} 5$ mulai terbentuk $\mathrm{Pb}(\mathrm{OH})^{-}$yang kurang berinteraksi dengan gugus dari biomassa daun ketapang. Pada $\mathrm{pH} \quad 6$ hingga $\mathrm{pH} \quad 10 \quad \mathrm{~Pb}$ cenderung membentuk $\mathrm{Pb}(\mathrm{OH})_{2}$ yang kurang berinteraksi dengan gugus biomassa, ini dibuktikan dengan kecenderungan penurunan kapasitas adsorpsi pada saat $\mathrm{pH}$ 6 hingga $\mathrm{pH} 10$. 
Molekul, Vol. 10. No. 1. Mei, 2015: 45 - 56

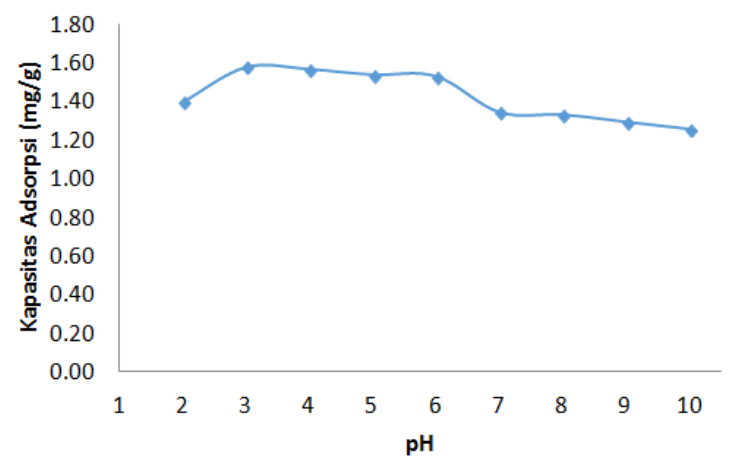

Gambar 3 Kurva Hubungan Antara pH dengan Kapasitas Adsorpsi

Pengaruh Massa Adsorben

Berdasarkan hasil penelitian dosis adsorben dapat dilihat pada Gambar 4 kapasitas adsorpsi yang turun drastis pada peningkatan biosorben dari 0,1 menjadi 5 gram. Hal ini disebabkan meningkatnya jumlah sisi aktif untuk mengikat $\mathrm{Pb}^{2+}$ dengan meningkatnya jumlah biosorben. Pada rentang tertentu kenaikan kapasitas adsorpsi menjadi tidak signifikan. Hal ini terjadi karena peningkatan sisi aktif tidak dibarengi dengan peningkatan volume media air sebagai tempat berjalannya reaksi.

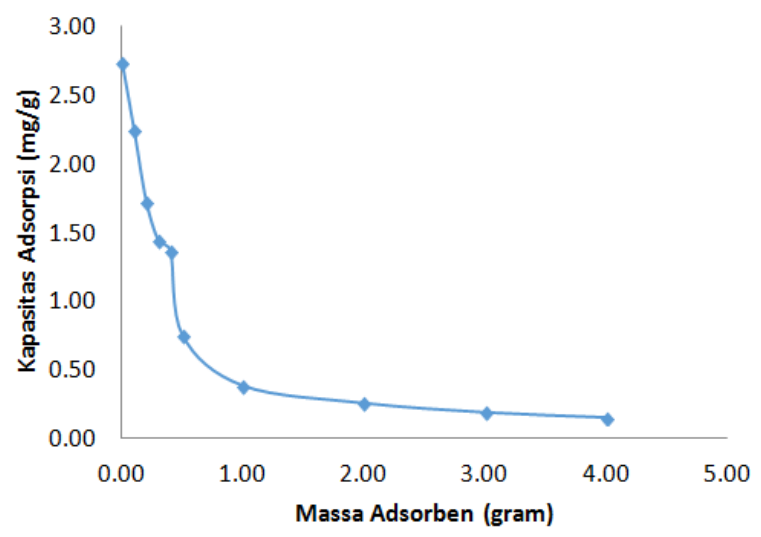

Gambar 4. Kurva Hubungan Antara Massa Adsorben dengan Kapasitas Adsorpsi.

Peningkatan konsentrasi biomassa umumnya meningkatkan jumlah zat terlarut biosorben dimana luas permukaan meningkat sehingga jumlah logam yang terikat akan lebih banyak. Sebaliknya, jumlah zat terlarut biosorben per satuan berat pada satu titik tertentu akan menurun seiring bertambahnya dosis biosorben. Fenomena ini diduga akibat kejenuhan poripori permukaan biosorben yang telah dipenuhi oleh logam berat sehingga biosorben tidak mampu menyerap kembali.
Data ini sejalan dengan teori adsorpsi Langmuir yang menyatakan bahwa permukaan adsorben memiliki sejumlah tertentu situs aktif (active site) adsorpsi. Oscik dan Cooper (1992) menjelaskan bahwa banyaknya situs aktif sebanding dengan luas permukaan biosorben dan masing-masing situs aktif hanya dapat mengadsorpsi satu molekul adsorbat. Pada keadaan dimana tempat adsorpsi jenuh dengan adsorbat maka kenaikan jumlah biosorben cenderung tidak menaikkan jumlah zat yang teradsorpsi. 


\section{Pengaruh Konsentrasi Pb}

Berdasarkan Gambar 5 variasi konsentrasi dilakukan untuk melihat pada konsentrasi berapa biosorben dapat bekerja lebih baik mengingat larutan yang digunakan adalah limbah artifisial. Pengaruh konsentrasi pada proses adsorpsi dapat dijelaskan dengan teori tumbukan. Semakin tinggi konsentrasi menandakan semakin banyak molekul dalam setiap satuan luas ruangan, dengan demikian tumbukan antar molekul akan semakin sering terjadi. Semakin banyak tumbukan yang terjadi berarti kemungkinan untuk menghasilkan tumbukan yang efektif akan semakin besar sehingga reaksi berlangsung lebih cepat (Widianti, 2010).

Mekanisme penyerapan logam berat bergantung pada konsentrasi awal logam berat itu sendiri. Pada konsentrasi rendah logam berat teradsorbsi oleh situs spesifik, sementara peningkatan konsentrasi logam akan mengakibatkan situs spesifik menjadi jenuh dan situs pertukaran (exchange sites) akan penuh terisi (Saeed, et al., dkk, 2005). Kapasitas adsorpsi pada ketiga jenis biosorben meningkat seiring dengan bertambahnya konsentrasi awal logam pada larutan.

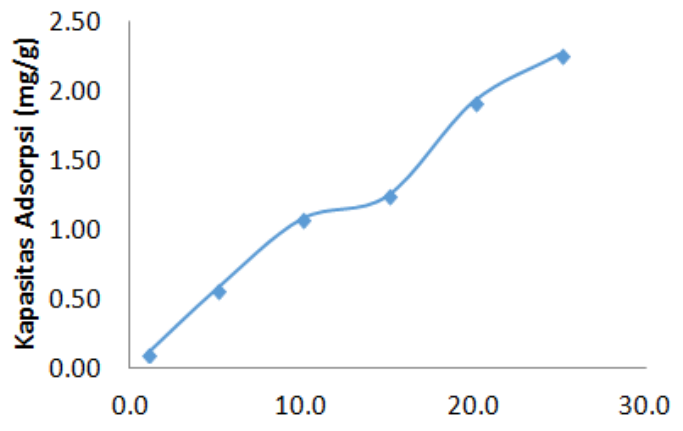

Gambar 5 Kurva Hubungan Antara Konsentrasi $\mathrm{Pb}^{2+}$ dengan Kapasitas Adsorpsi.

\section{Pengaruh Suhu Adsorpsi $\mathbf{P b}^{2+}$}

Hasil pengujian daun ketapang murni dan perlakuan asam basa dengan pengaruh suhu dapat di lihat pada Gambar 6. Daun ketapang dengan kenaikan suhu mengalami kenaikan serapan hingga suhu $40{ }^{\circ} \mathrm{C}$ dan sedikit turun dengan kenaikan suhu hingga $50{ }^{\circ} \mathrm{C}$. Hal ini disebabkan oleh kenaikan jumlah gugus aktif yang dihasilkan oleh protonasi/deprotonasi gugus fungsi dalam biosorben. hal ini dikarenakan kenaikan suhu menyebabkan tumbukkan antar molekul meningkat (Atkins, 1999), tetapi ketika suhu semakin tinggi dan tumbukkan semakin banyak terjadi kestabilan akan terganggu (Rumidatul, 2006). Hal ini tidak sejalan dengan penelitian yang dilakukan oleh Mujtahid (2005) yang menyatakan suhu tidak berpengaruh signifikan pada chemisorption karena molekul yang bereaksi sedikit dan laju reaksi berjalan cepat, yang menggunakan chitin sebagai adsorben logam timbal. Pengaruh suhu dalam kinetika kimia dinyatakan oleh Largitte (2014) mendapatkan suhu sangat berpengaruh dalam penyerapan logam timbal dalam larutan menggunakan presipitasi karbon aktif batok kelapa. 
Molekul, Vol. 10. No. 1. Mei, 2015: 45 - 56

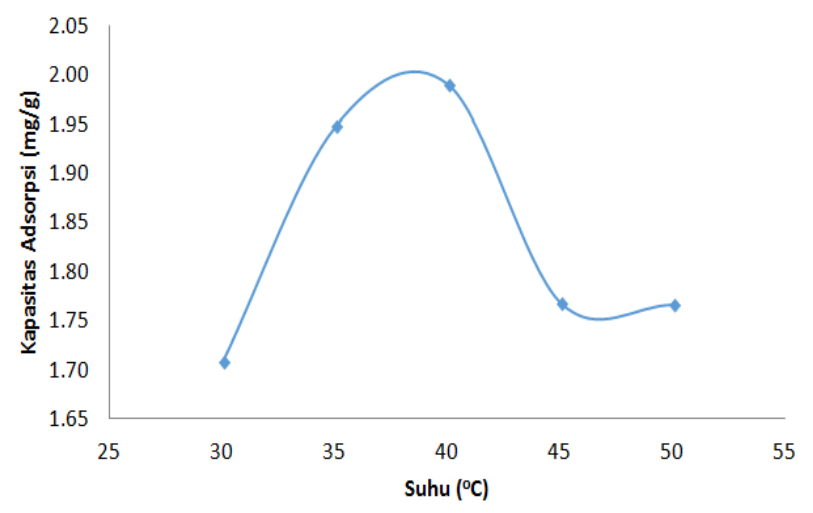

Gambar 6. Kurva Hubungan Suhu dengan Kapasitas Adsorpsi

\section{Kinetika Reaksi Penyerapan}

Pengujian kinetika adsorpsi pada penelitian ini dibatasi pada pengujian orde reaksi. Orde reaksi yang diuji adalah orde 1, 2, dan 3. Kurva yang diperoleh pada berbagai orde reaksi diperlihatkan oleh Gambar 7. Nilai $r$ yang diperoleh dari ketiga orde tersebut dibandingkan dengan nilai $r$ yang paling mendekati 1 menunjukkan bahwa kurva yang linier dengan penyerapan $\mathrm{Pb}^{2+}$ berjalan mengikuti orde yang ditunjuk kurva tersebut.

Reaksi berjalan pada orde 1 dan bukan orde 2 atau orde 3 karena nilai $\mathrm{R}^{2}$ yang mendekati 1 hanya reaksi orde 1 , sedangkan reaksi orde 2 dan orde 3 sangat jauh nilai $\mathrm{R}^{2}$ dari 1 , seperti terlihat pada dapat diketahui bahwa laju reaksi adsorpsi $\mathrm{Pb}^{2+}$ dengan adsorben daun ketapang murni, daun ketapang diasamkan, dan daun ketapang dibasakan berjalan pada reaksi orde 1 , yang menunjukkan reaksi ini bergantung pada konsentrasi reaktan dan berbanding lurus dengan konsentrasi pereaksi.

Tabel. 2 Nilai r Orde 1, Orde 2, dan Orde 3

\begin{tabular}{lccc}
\hline & & Orde 1 \\
& $\mathbf{1}$ & $\mathbf{2}$ & $\mathbf{3}$ \\
\hline $\mathrm{r}$ & & - & - \\
& 0,93 & 0,79 & 0,76 \\
slope & 0,18 & - & - \\
intercept & 1,06 & 0,30 & 0,01 \\
\hline
\end{tabular}
Tabel 2. Dari Gambar 2 hingga Gambar 5

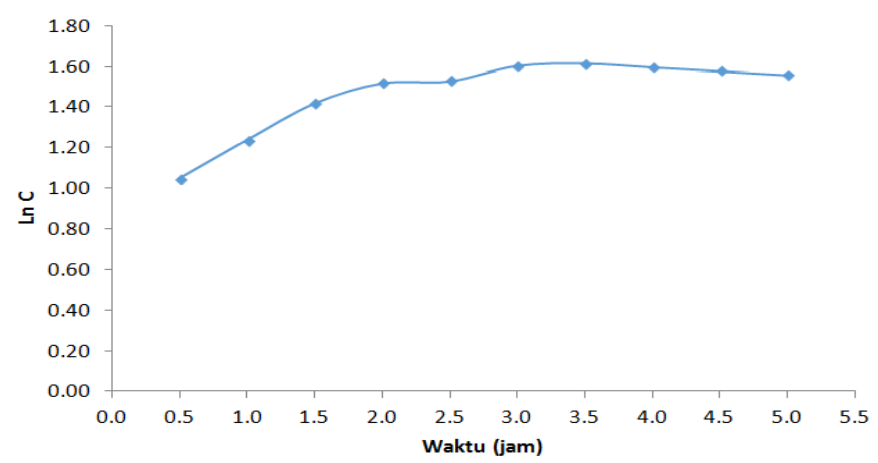

Gambar 7. Laju Reaksi Orde 1 Biomasa

\section{Isotermal Adsorpsi}

Penentuan isotermal adsorpsi bertujuan untuk melihat penyerapan dari biosorben pada proses adsorpsi. Dari persamaan isoterm adsorpsi dapat dilihat karakteristik isoterm berupa kapasitas dan mekanisme 
proses biosorpsi. Persamaan isoterm yang digunakan dalam penelitian ini adalah persamaan Freundlich dan persamaan Langmuir (Atkin, 1999). Dari hasil perhitungan dibentuk kurva linear antara 1/Ce dan 1/qe untuk persamaan Langmuir. Persamaan isoterm yang sesuai dengan percobaan ini dapat dibuktikan melalui koefisien determinasi (R2) yang ditunjukkan pada grafik linearisasi masing-masing persamaan.

Konstanta isoterm Langmuir menunjukkan pola ikatan yang terbentuk antara biosorben dan adsorbat. Nilai qm dari Langmuir menggambarkan ikatan antara biosorben dan logam $\mathrm{Pb}^{2+}$ mampu membentuk lapisan monolayer dalam jumlah besar. Apabila biosorben mencapai nilai qm, maka kapasitas adsorpsi mencapai angka maksimum atau mengalami titik jenuh dimana seluruh situs penyerapan telah penuh dan kemudian terbentuk lapisan pada permukaan adsorben. Nilai KL mengindikasikan tingkat afinitas antara $\mathrm{Pb}^{2+}$ dengan permukaan biosorben. Nilai K > 1 menunjukkan tingkat afinitas yang kuat.

Tabel 3 Nilai $r$, slope dan intercept Persamaan Langmuir dan Freundlich

\begin{tabular}{lr}
\hline & Langmuir \\
\hline $\mathrm{r}$ & 0,99 \\
slope & 5,0 \\
intercept & 0,0 \\
\hline
\end{tabular}

\section{KESIMPULAN}

Berdasarkan penelitian pada
percobaan dan perhitungan dapat
disimpulkan bahwa biomassa daun ketapang
berpotensi sebagai biosorben. Penyerapan
sangat dipengaruhi oleh $\mathrm{pH}$, konsentrasi ion
$\mathrm{Pb}$, massa adsorben, waktu kontak dan suhu,
yang berurutan nilai maksimum nya adalah
$\mathrm{pH} \mathrm{3,} \mathrm{konsentrasi} \mathrm{ion} \mathrm{Pb} 5 \mathrm{mg} / \mathrm{L}$, massa
adsorben 0,5 gram, waktu kontak 4 jam, dan

suhu $40{ }^{\circ} \mathrm{C}$. Laju reaksi berjalan pada orde satu dan memenuhi kaidah isotermal Langmuir. Daun ketapang murni mempunyai memiliki energi aktivasi yang rendah mencirikan interaksi fisisorpsi.

\section{SARAN}

Saran untuk kelanjuttan penelitian ini adalah penelitian lanjutkan untuk melihat potensi biomassa sebagai adsorben logam berbahaya lainnya. Pengaruh leaching bahan organik dalam proses adsorpsi .

\section{DAFTAR PUSTAKA}

Atkins, PW. 1999. Kimia Fisik. Jilid I dan II. Irma I Kartohadiprojo, penerjemah; Rohdyan T, Hadiyana $\mathrm{K}$, editor. Erlangga. Jakarta. Terjemahan dari Physical Chemistry.

Chao, H., and Chang, C 2012. Adsorption Of Copper(II), Cadmium(II), Nickel(II) And Lead(II) From Aqueous Solution Using Biosorbents. Adsorption 18:395-401 DOI 10.1007/s10450-012-9418-y. Springer

Jiang. H., Tingqiang L., Xuan H., Xiaoe Y., Zhenli H. 2012. Effects of $\mathrm{pH}$ and low molecular weight organic acids on competitive adsorption and desorption of cadmium and lead in paddy soils. Environ Monit Assess 184:6325-6335. Springer

Ismayadi S. 2010. Kajian Tingkat Toleransi Jenis-Jenis Pohon Sebagai Penyerap Dan Penjerap Polutan Timbal $(\mathrm{Pb})$ Dan $\mathrm{Cd} \mathrm{Dl}$ Berbagai Tipe Curah Hujan. Pusat Penelitian Dan Pengembangan Konservasi Dan Rehabilitasi Badan Penelitian Dan Pengembangan Kehutanan Kementrian Kehutanan RI.

Klimmek, Stan, Wilke, Bunke, Buchholz. (2001). Comparative Analysis of The Biosorption of Cadmium, Lead, 
Nickel, and Zinc by Algae., Environment Science Technology.35, 4283-4288

Largitte (2014). Removal of lead from aqueous solutions by adsorption with surface precipitation. Adsorption (2014) 20:689-700. Springer.

Lim. 2012 Edible Medicinal And NonMedicinal Plants: Volume 2, Fruits, 143 DOI 10.1007/978-94-007-17640_24, () Springer Science+Business Media B.V.

Mawardi. 2007. Kajian Biosorpsi Ion-Ion Logam Berat Oleh Biomassa Alga Hijau Spirogyra subalsa. Disertasi Universitas Indonesia.

Mujtahid, K. 2005. Kesetimbangan Adsorpsi Logam Berat $\mathrm{Pb}$ Dengan Adsorben Chitin Secara Batch. E k u i li bri u $m$ vol. 4 no. 1 Juni

Oscik, J., \& Cooper, I. L. (1992). Adsoption. Ellis Horwood Publisher Limited, Chichester.

Ramakul, P. 2012. Biosorption of palladium(II) and platinum(IV) from aqueous solution using tannin from Indian almond (Terminalia catappa
L.) leaf biomass: Kinetic and equilibrium studies. 2012. Elsevier.

Rumidatul, A. (2006). Efektivitas Arang Aktif sebagai Adsorben pada Pengolahan Air Limbah. Tesis Departemen Teknologi Hasil Hutan. Institut Pertanian Bogor

Saeed, A., Waheed-Akhter, M., \& Iqbal, M. (2005). Removal and recovery of heavy metals from aqueous solution using papaya wood as a new biosorbent. Sep. Purif. Technol. 45: 25-31.

Stephen I., N. Sulochana.2006. Mercury adsorption on a carbon sorbent derived from fruit shell of Terminalia catappa. Journal of Hazardous Materials B133 (2006) 283-290

Widhianti, W. D. (2010). Pembuatan Arang Aktif dari Biji Kapuk (Cieba pentandra L.). Skripsi Departemen Kimia Fakultas Sains dan Teknologi. Universitas Airlangga Surabaya.

Zabihi, A. Ahmadpour, A. Haghighi Asl. 2009. Removal of mercury from water by carbonaceous sorbents derived from walnut shell. Journal of Hazardous Materials 167 230-236 